\title{
Sağlık Çalışanlarında Örgütsel Kronizm ve İşgören Performansı Arasındaki ilişkinin İncelenmesine Yönelik Bir Araştırma
}

\author{
Fatih ŞANTAŞ ${ }^{1}$ \\ Gülcan ŞANTAŞ² \\ Özlem ÖZER ${ }^{3}$ \\ Mehmet Bircan GÜLEÇ
}

Sağlık Çalışanlarında Örgütsel Kronizm ve İşgören Performansı Arasındaki İlişkinin İncelenmesine Yönelik Bir Araştırma

Öz

Bu çalışmanın amacı, sağlık çalışanlarının örgütsel kronizm ve işgören performansına ilişkin algılarını incelemek ve örgütsel kronizm algılarının işgören performansı üzerindeki etkisini ortaya koymaktır. Çalışmada, Antalya ilinde bir kamu hastanesinde çalışmaya katılmak isteyen tüm sağlık çalışanlarına anket uygulanmış ve 316 kullanılabilir anket elde edilmiştir. Bu çalışmada sağlık çalışanlarının örgütsel kronizm algılarının orta düzeyde ve işgören performansı algılarının ise yüksek düzeyde olduğu belirlenmiştir. Örgütsel kronizm boyutlarından işlem kronizminin mevcut hastanede çalışma süresi; terfide kronizmin eğitim, hastanedeki görev ve mevcut hastanede çalışma süresi ve işe alma sürecinde kronizmin ise cinsiyet ve mevcut hastanede çalışma süresine göre istatistiksel olarak anlamlı bir farklılık gösterdiği belirlenmiştir $(p<0,05)$. İşgören performansının ise yaş, eğitim düzeyi, hastanedeki görev ve mevcut hastanede çalışma süresine göre istatistiksel olarak anlamlı bir farklılık gösterdiği tespit edilmiştir $(p<0,05)$. Ayrıca katılımcıların örgütsel kronizm algılarının (işlem kronizmi, terfide kronizm ve işe alma sürecinde kronizm) yükselmesinin işgören performansı algılarını istatistiksel olarak azalttığı saptanmıştır. Bu sebeple örgütsel kronizm algısının düşürülmesi hem sağlık kurumları hem de sağlık çaIışanları açısından fayda sağlayacaktır.

Anahtar Kelimeler: Örgütsel Kronizm, İşgören Performansı, Sağlık Çalışanları, Hastane
A Research on the Relationship between Organizational Cronyism and Employee Performance in Health Employees

\section{Abstract}

This study aims to investigate the perceptions of health employees on organizational cronyism and employee performance, and to reveal the impact of organizational cronyism perceptions on employee performance. Survey was applied to all health employees who wanted to participate in a public hospital in Antalya province, and 316 available surveys were obtained in the study. It was determined that health employees' perceptions of organizational cronyism were moderate and perceptions of employee performance were high. It was determined that the process chronism showed a statistically significant difference according to the working time in current hospital; cronyism in promotion showed a statistically significant difference according to education, position at hospital and working time in current hospital; cronyism in the recruitment process showed a statistically significant difference according to the gender and working time in current hospital $(p<0.05)$. It was identified that employee performance was statistically significant according to age, education level, position in hospital and working time in current hospital $(p<0.05)$. Also, it was determined that the participants' perceptions of organizational cronyism (transaction cronyism, promotion cronyism and cronyism in the recruitment process) decreased statistically the perceptions of employee performance. For this reason, the reduction of organizational cronyism perception will be beneficial both for health institutions and for health employees.

Keywords: Organizational Cronyism, Employee Performance, Health Employees, Hospital

\section{Giriş}

Örgütsel kronizm, örgüt alanyazını ile ilgilenen araştırmacıların dikkatini çeken konular arasındadır (Turhan, 2014; Khatri vd., 2006; Khatri ve Tsang, 2003). Örgütsel işlevsellik üzerinde

\footnotetext{
${ }^{1}$ Dr. Öğr. Üyesi, Yozgat Bozok Üniversitesi IïBF, Sağlık Yönetimi Bölümü. fatih.santas@bozok.edu.tr, yazar ORCID bilgisi: https://orcid.org/0000-0002-0595-4183.

2 Dr. Öğr. Üyesi, Yozgat Bozok Üniversitesi iiBF, Sağlık Yönetimi Bölümü. gulcansantas@gmail.com, yazar ORCID bilgisi: https://orcid.org/0000-0002-0488-9375.

${ }^{3}$ Dr. Öğr. Üyesi, Mehmet Akif Ersoy Üniversitesi iïBF, Sağlık Yönetimi Bölümü. oozer@mehmetakif.edu.tr, yazar ORCID bilgisi: https://orcid.org/0000-0002-7238-5371.

4 Hastane Müdürü, Akdeniz Üniversitesi Hastanesi. mbgulec@akdeniz.edu.tr, yazar ORCID bilgisi: http://orcid.org/0000-0001-8285-8198.
} 
potansiyel olumsuz etkilere yol açması sebebiyle, örgütsel kronizm ile ilgili endişeler gündeme getirilmektedir (Shaheen vd., 2017:309).

Örgütlerde kronizm, işgörenlerin istihdamında liyakat ve eşitlik ilkeleri yerine eş- dost ilişkilerinin esas alınması suretiyle yapılan kayırmacılık olarak ifade edilmektedir (Erdem vd., 2013: 55). Kronizm örgüt işlevselliğine, örgüt performansı yoluyla etki edebilmektedir. Siyaset bilimi, ekonomi ve antropoloji alanlarında kronizm ile ilgili yapılan çalışmalarda, kronizmin örgütsel performansı olumsuz şekilde etkilediği belirtilmektedir (Pearce, 2015: 43; Coco ve Lagravinese, 2014: 444). Örgüt içine yerleşen kronizmin örgütsel performansı tehlikeye atacağına ve kronizm ile boğuşan örgütlerin etkin olma olasılığının düşük olabileceğine işaret edilmektedir (Yan ve Bei, 2009:4). Örgütsel kronizmin hızlı terfi, maaşta iyileşme gibi sonuçları bulunmakla birlikte, örgütsel performansa etkileri genellikle olumsuz olmaktadır (Gürer ve Deniz, 2017:477; Shabbir ve Siddique, 2017:299).

Sağlık kurumları ölçeğinde düşünüldüğünde, sağlık hizmetleri genellikle sürekli iletişim gerektiren ekip işlerinden oluşmaktadır. Ekibi oluşturan her bir çalışan sağlığın korunması, teşhis, tedavi, rehabilitasyon gibi pek çok alanda hizmetlerin sunulması ve iyileştirilmesi amacıyla performans sergilemektedir. Ancak örgüt içinde terfi, işe alım ve diğer işlemlerde liyakat yoluyla değil de kayırmacılık yapılarak değerlendirilme yapılması durumunda, örgüt çalışanlarının performansı azalabilmektedir. Genel anlamda örgüt performansı bu kayırmacılığın etkisiyle zarar görebilmektedir.

Sağlık kurumlarında örgütsel kronizmin işgören performansına yansımalarını ele alan bir çaıışmaya rastlanılmaması nedeniyle bu çalışmanın ilgili alanyazına katkı sağlayacağı düşünülmektedir. Çalışmada anket yardımıyla sağılık çalışanlarında örgütsel kronizm ve işgören performansı arasındaki ilişki araştırılacaktır.

\section{Kavramsal Çerçeve}

\section{1. Örgütsel Kronizm}

Örgütsel kronizm, bir "yönetim hastalı̆̆ı" olarak ifade edilmektedir (Büte, 2011:386). Kronizm, yakın dostlar anlamına gelen "crony" kelimesinden türemiştir ve özellikle politikada niteliklere bakılmaksızın çalışanların görevlendirilmesini konu edinmektedir (Arasli ve Tumer, 2008: 1239). Kronizm, örgüt içinde çalışanların işe alım sürecinde ve çalışma ortamında terfi imkânları ortaya çıktığında eş-dost ilişkilerini dikkate alarak çalışanların göreve getirilmesi olarak ifade edilmektedir (Gürer ve Deniz, 2017:477). Bir başka tanımda ise örgütsel kronizm, yöneticinin belirli çalışanlara yönelik ayrıcalıklı yaklaşımları şeklinde tanımlanmaktadır. Bu yaklaşımlar, performans kriterleri ya da resmi prosedürlerle ilgili olmayan kişisel ilişkiler, kişisel bağlıık gibi faktörlerden kaynaklanmaktadır (Turhan, 2014:301). Kronizm, kamu kurumlarında ve özel sektörde ekonomik ilişkiler kurmaya öncelik vermek şeklinde de ele alınmaktadır (Ergun Ozler ve Buyukarslan, 2011:278). Ayrıca örgütsel kronizmin, yozlaşma ve dejenerasyon olayı olarak incelendiği de görülmektedir (Erdem ve Karataş, 2015:57). Birçok farklı ilişki ağı üzerinden tanımı yapılan kronizm, bu çalışma kapsamında kullanılan ölçeğe en yakın anlamı çağrıştırması nedeniyle "kamu görevlilerinin ya da diğer örgüt çalışanlarının istihdamında liyakat ve eşitlik ilkeleri yerine eş- dost ilişkilerinin esas alınması suretiyle yapılan kayırmacılık" olarak ele alınmıştır (Erdem vd., 2013: 55).

Alanyazın incelendiğinde kronizm kavramının nepotizm, favorizm ve tribalizm kavramlarıyla sıkça karıştıııldığı ve bu kavramların birbirlerinin yerine kullanıldığı görülmektedir. Karıştırılan bu kavramları "kayırmacılık" başlığı altında toplamak mümkündür. Kayırmacılık, kişilerin veya 
belirli bir grubun lehine olacak şekilde çıkar sağlanması olarak ifade edilebilmektedir (Tunçbilek ve Akkuş, 2017:170). Kayırmacılığın alt başıklarından biri olan nepotizmde, akraba ve kan bağı yoluyla kişilere istihdam olanaklarının sunulması amaçlanmaktadır (Erdem vd., 2013:55). Nepotizm, ailenin menfaatleri gereği içinde bulunulan mevki ve pozisyonun suiistimal edilmesi şeklinde ifade edilebilmektedir (Abdalla vd., 1998:555). Bir diğer kayırmacılık türü olan favorizm, bir tür çıkar çatışması içermektedir ve kişisel, idari ya da politik iyiliklere ulaşmak için insan kaynakları yönetimi kararlarına müdahalede bulunma ve kararlara etki etmeyi içermektedir. Favorizmin örnekleri olarak kişisel beğeni ve itaate bağlı olarak çalışanlara yüksek performans notu verme, maaş artışı veya terfide kayırma verilebilmektedir. Bu tür kayırmacılık örnekleri, insan kaynakları uygulamalarının amaçlarına ters şekilde kişisel tercihler ile şekillenmektedir (Ashour, 2004:15). Aynı kabile veya aşirete mensup bireylerin kayırılması ise tribalizm olarak ifade edilmektedir (Loewe vd., 2007:21). Kronizmde ise işe alım ve terfi sürecinde çalışanın eş-dost, tanıdık, arkadaş, hemşeri gibi kişiler tarafından göreve getirilmesi önemli olmaktadır.

Khatri ve Tsang (2003: 297), kronizmi oluşturan bazı durumlardan bahsetmektedir. Yapılan iyilik zaman içinde cevaplanabilir veya bu cevap bir sözleşme ile açıkça sabit değilse; değerli bir şey verilmişse; taraflar aynı sosyal ağda yer alıyorsa ve üçüncü bir tarafın dezavantajı söz konusuysa örgüt içinde kronizm olduğu söylenebilmektedir. Genellikle örgüt içinde kronizm, bazı çaIışanların ilişki ve bağlantılar temel alınarak diğerlerine göre daha fazla desteklenmesiyle ortaya çıkmaktadır (Shaheen vd., 2017:308). Kronizmde, belirli grupların diğerlerine göre daha fazla yarar sağladığı sosyal ağ yapıları oluşmaktadır. Bu tür yapılarda örgüt yöneticileri, performansa bağlı olmayan faktörlere veya karşııklı lehte alışverişe dayalı olarak kararlar verebilmektedir. Kronizmin odak noktası bazı kültürlerde gayri resmi grup üyeliğinin devam etmesi iken, bazı kültürlerde patronaj ilişkileri, kişisel fayda ve beklentiler olmaktadır (Turhan, 2014:295-297). Kronizm, bazı kültürlerde tolere edilse de haksız rekabetten verimsizlikler yaratarak toplumsal maliyetleri artırmaktadır. Ayrıca, toplumsal kurumlara olan güveni azaltabilmekte ve vatandaşlar arasındaki çıkar ilişkisini tetikleyebilmektedir (Khatri vd., 2006:63).

Örgütsel kronizm, yatay (akran) kronizm ve dikey (hiyerarşik) kronizm olmak üzere iki şekilde ortaya çıkmaktadır. Yatay kronizmde aynı düzeyde ilişki temelli bir kronizm söz konusudur. Akran kronizmi olarak da ifade edilmekte ve göreceli eşitliğin olduğu iş ortakları, arkadaşlar, meslektaşlar, sınıf arkadaşları, sosyal gruplar ve sendikalar arasında görülmektedir. Dikey ya da hiyerarşik kronizm ise, performansın performansa bağlı olmayan faktörler temelinde bir alt grubun lehine değerlendirilmesinde lider ve takipçisi arasındaki ilişki şeklinde tanımlanmaktadır (Khatri vd., 2006:64). Farklı hiyerarşik düzeylerde ast-üst ilişkisi şeklinde görülmektedir (Gürer ve Deniz, 2017:478). Her aktör, hiyerarşi boyunca kronizmi kademeli olarak aramaktadır. Elde ettiği kronizm, hiyerarşi içindeki konumlandırmasına bağlı olmaktadır (Leung ve Barnes, 2016:7).

Örgütsel kronizm; terfide kronizm, işlem kronizmi ve işe alma sürecinde kronizm olmak üzere üç boyutta ele alınmaktadır. Buna göre; bilgi, beceri ve kabiliyetler yerine işin gerektirdiği nitelikler dışındaki faktörler terfide kullanıldığında, örgüt içinde terfide kronizm yapıldığı söylenebilmektedir. İşlem kronizmi, örgüt içi işlemlerde (davranış, ceza, işten çıkarma, işletme kaynaklarını kullanma, yetki devri vb.) bir gruba ayrıcalıklı davranılmasıyla ortaya çıkmaktadır. İşe alma sürecinde kronizm ise, örgüte insan kaynağı temin etme sürecinde yönetim kadrosunda bulunan kişilerin referansları dikkate alındığında meydana gelmektedir (Erdem vd., 2013:63).

Örgütsel kronizmin pek çok örgütsel düzeyde önemli sonucu bulunmaktadır (Khatri ve Tsang, 2003:296). Kavram, işletmelerin kurumsallaşmasını olumsuz şekilde etkileyebilmekte ve 
işletme yönetiminin bu süreci iyi yönetme yeteneğini engelleyebilmektedir (Keleş vd., 2011:10). Kronizm, insani ve hoşgörülü bir iş ortamına katkı sağlayan ve örgütsel performansı artırabilen sosyal ilişkilere zarar verebilmektedir (Pearce, 2015: 43). Yetersiz ve niteliksiz adayların örgüte dâhil olması, örgütsel kronizme olumsuz yaklaşılmasının sebepleri arasındadır (Fu, 2015:5). Kronizm, örgütün tepesindeki birkaç kişinin güçlenmesine hizmet ederken, örgütün değişiklikleri öğrenme ve bunlara uyum sağlama yeteneği üzerinde bir kısıtlama getirmektedir (Khatri ve Tsang, 2003: 298). Yeteneklerinin üzerinde iltimas gören çalışanların varlığı, diğer çalışanların huzursuzluğuna yol açabilmektedir (Özer ve Çağlayan, 2016:20).

Feinberg (2018), kronizmin muhtemel örgütsel sonuçlarını şu şekilde özetlemektedir: Çalıştıkları kurumlarda yöneticilerin gözüne girmeye çalışan personel, örgüt için doğru olanı yapmaktan ziyade yöneticinin söylediği her şeyi yanlış bile olsa yapmaya çalışabilmektedir. Bu durum da örgüte zararı olan kararların alınmasına sebep olabilmektedir. Kronizm, örgüt içinde rakip takımların oluşmasına, örgüt içinde negatif stresin artmasına, bu takımların ekip olarak birlikte çalışamaz hale gelmesine ve çalışanların düşük performans göstermesine yol açabilmektedir. Örgüt içinde ortaya çıkan kronizmle birlikte problem çözmede yetersizlikler, siyaset ve çatışmalara dayanan bürokrasi, yanlış kararlar, personel sorunları, reaktif liderlik, iyi yeteneklerin kaybı, çalışanların moralinde düşüş, örgüt sadakatinin kaybedilmesi, hesap verilebilirliğin eksilmesi ve kısıtlı büyüme koşulları gibi sorunlarla karşılaşılabilmektedir.

\section{2. İşgören Performansı}

İşgören performansı, örgüt performansının önemli belirleyicilerinden birisidir (Kesen ve Kaya, 2016:190; İraz ve Akgün, 2011:228). Performans, üretilen mal ve hizmetin miktarını yansıtırken; bireysel performans, bireyin hedefi başarmadaki verimliliği ve etkinlik düzeyini ifade etmektedir (Tutar ve Altınöz, 2010:201). İ̧gören tarafından yapılan işin hedefe ne kadar yaklaşıldığını göstermesi açısından performans önemli olmaktadır (Bekiş vd., 2013:21). Performans, bireyden bireye farklılık gösteren bir olgudur ve örgütsel faktörler işgören performansını farklı seviyelerde etkileyebilmektedir (Güner, 2015:11).

Örgütlerin başarısı, büyük oranda işgörenlerin performansına bağlı olmaktadır (Cemaloğlu, 2007:121). İşgören performansı, örgüt performansına katma değer sağlayan ve onu etkileyebilme potansiyeli olan önemli bir belirleyicidir. Bireysel anlamda işgören performansının artırılması, örgütün performansını da artırmaktadır (Çöl, 2008:45). Hedefe ulaşmada ve sektörün rekabet gücünü artırmada, iş performansı yüksek olan çalışanlar önemli rol oynamaktadır (Yelboğa, 2006:200). Sağlık kurumları emek ve teknoloji yoğun kurumlar olduğu için, çalışanın iş verimi ve performansı sağlık hizmetleri sunumunun başarısında önemli rol oynamaktadır.

\section{3. Örgütsel Kronizm ve İşgören Performansı iliş̧kisi}

Alanyazın incelendiğinde örgütsel kronizm ve işgören performansı arasındaki ilişkiyi inceleyen çalışma sayısının kısıtlı olduğu görülmektedir. Khatri ve Tsang (2003: 298), kronizmin örgütlere nüfuz ettiğinde örgüt performansının tehlikeye girdiğini; işgörenlerin verimliliğinin ve performansının azaldığını ve kronizm ile mücadele eden örgütlerin verimli olmasının ve rekabetçi bir ortamda hayatta kalabilmelerinin olası olmadığını belirtmektedir.

Örgüt içinde kronizm algısı ortaya çıkmaya başladığında ve yetkinlikten ziyade sadakate dayalı olarak ödüllendirildiklerini fark ettiklerinde, çalışanlar en iyi ihtimalle ortalama performans gösterebilirler. Dahası, enerjilerini ve dikkatlerini örgüte katkı sağlamasa bile yöneticiyle uyumlu kararlar almaya yöneltebilirler. Bu durum, çalışanların iş sorumluluklarını ve görevlerini 
tamamlamalarını engelleyebilir. Dolayısıyla, iş performansı kronizm algısından olumsuz şekilde etkilenebilir (Feinberg, 2018).

Eğitim sektöründe öğrenciler üzerinde gerçekleştirilen bir çalışmada, kronizmin beceri edinimi için teşvikleri azalttığı ve dolayısıyla öğrencilerin performanslarını azalttığı bulgusu elde edilmiştir. Daha fazla kronizm, öğrencilerde beceri ediniminde daha az çaba ve daha az üretkenlik anlamına gelmektedir (Coco ve Lagravinese, 2014). Pakistan'da eğitim, kalkınma, bankacılık gibi kamu ve özel sektörlerde çalışanlar üzerinde yürütülen bir çalışmada, örgütsel performans üzerinde kronizm, nepotizm ve favorizm algısını dindarlığın aracılık rolüyle incelemek amaçlanmıştır. Çalışma sonucunda, nepotizm, kronizm ve favorizmin örgütsel performansı negatif yönde etkilediği ve üretkenliği azalttığı tespit edilmiştir. Aynı zamanda dindarlı̆̆ın bu olumsuz ilişkiyi zayıflattığı ve çalışanları kurumda olumlu olarak çalışmaya teşvik ettiği belirlenmiştir (Shabbir ve Siddique, 2017). Nevşehir'de belediye çalışanlarında kronizm, iş performansı ve örgütsel güven arasındaki ilişki incelenmiştir. Çalışma sonucunda, kronizmin ve örgütsel güvenin her zaman daha düşük performansa yol açmayacağı tespit edilmiştir. Kronizm ve örgütsel güven birlikte iş performansı ile ilişkili olmaktadır (Cingöz ve Akilli, 2015).

Sağlık kurumları ölçeğinde örgütsel kronizm ve işgören performansı ilişkisini inceleyen çaış̧ma sayısının sınırlı olduğu görülmektedir. Davis (2017), kronizmi arkadaş veya favori çalışanları eğitim ve deneyimden ziyade beğeniye göre pozisyonlara yerleştirme olarak ele almaktadır. Sağlık kurumlarında kronizmin yerleşmesi sonucunda, insanları mümkün olan en iyi sağlık hizmetlerinden mahrum edebilecek niteliksiz sağlık hizmeti sunucularının ortaya çıkması riskiyle karşılaşılabilir. Sağlık kurumlarında sağlık hizmetleri sunumuna katkı sağlayan çalışanlar yıllarca hastane ve diğer sağlık kurumlarında sağlık ile ilgili eğitimler almaktadır. Bu kurumlarda kişisel ilişkiler veya başka bir kayırmacılığa dayalı olarak pozisyonlara getirilen çalışanlar, getirildikleri pozisyonlara yönelik eğitim görmediklerinde, örgütün ve personelin etkililiği azalabilmekte ve çalışanların tutum ve algıları da olumsuz etkilenmektedir. Sağlık hizmetleri, tıbbi araştırmalar veya hasta bakımı ile ilgili kararlarda niteliksiz kişilerin yerleştirilmesini desteklemesi sebebiyle, kronizm sağlık hizmetleri sunumuna zarar vermektedir.

\section{Araştırmanın Yöntemi}

\subsection{Araştırmanın Amacı ve Önemi}

Bu araştırmanın amacı, sağlık çalışanlarının örgütsel kronizm ve işgören performansına ilişkin algılarını incelemek ve örgütsel kronizm algılarının işgören performansları üzerindeki etkisini ortaya koymaktır. Araştırmanın amaçları doğrultusunda aşağıdaki sorulara yanıt aranmıştır:

- Çalışanların örgütsel kronizm boyutlarına (işlem kronizmi, terfide kronizm ve işe alma sürecinde kronizm) ve işgören performansına ilişkin algıları yaş, cinsiyet, eğitim durumu, görev gibi kişisel özelliklerine göre farklılaşmakta mıdır?

- Çalışanların örgütsel kronizm algılarının (işlem kronizmi, terfide kronizm ve işe alma sürecinde kronizm) işgören performansı üzerindeki etkileri nasıldır?

\subsection{Araştırmanın Etik Yönü}

Bu çalışma için Mehmet Akif Ersoy Üniversitesi Etik Kurulu'ndan 03.01.2018 tarih ve 2018/9 sayılı etik izni alınmıştır.

\subsection{Evren ve Örneklem}

Araştırmanın evrenini Antalya ilinde bir kamu hastanesinde çalışan hemşire, sağıık çalışanı ve idari personel oluşturmaktadır $(\mathrm{N}=1000)$. Çalışmada, hastanede görev yapmakta olan tüm 
çalışanlara ulaşılması hedeflenmiş olup, çalışma sonucunda 316 anketin geri dönüşü sağlanabilmiştir. Araştırma, 20.01.2018-20.02.2018 tarihleri arasında gerçekleştirilmiştir.

\subsection{Veri Toplama Araçları}

Araştırmada veri toplama aracı olarak anket kullanılmıştır. Anket, toplam 26 sorunun yer aldığı üç bölümden oluşmaktadır. Birinci bölümde katılımcıların kişisel ve demografik bilgilerini ölçmeye yönelik 6 soru bulunmaktadır. İkinci bölümde "Örgütsel Kronizm Ölçeği” ve üçüncü bölümde ise "Iş̧gören Performansı Ölçeği" yer almaktadır. Ankette kişisel ve demografik bilgiler bölümü hariç, 1 (Kesinlikle Katılmıyorum) ve 5 (Kesinlikle Katılıyorum) arasında değerler alan 5’li Likert tipi ölçek kullanılmıştır.

Çalışmada örgütsel kronizmin ölçümünde Abdalla ve diğerleri (1998) ile Ford ve McLaughin (1985) tarafından geliştirilen ve Türkçeye çevirisi, Büte ve Tekarslan (2010) ile Asunakutlu ve Avcı (2010) tarafından yapılmış ve Erdem vd. (2013) tarafından da geçerlik ve güvenirliği sınanan "Örgütsel Kronizm Ölçeği” kullanılmıştır. Ölçek, "işlem kronizmi, terfide kronizm ve işe alma sürecinde kronizm" olmak üzere üç boyut ve 16 ifadeden oluşmaktadır.

Katılımcıların işgören performans algıları ise, Kirkman ve Rosen (1999) ile Sigler ve Pearson (2000) tarafından yapılan çalışmalarda kullanılan "Işgören Performansı Ölçeği" aracılığıyla ölçülmüştür. Ölçek tek boyutlu olup, dört ifadeden oluşmaktadır.

\subsection{Verilerin Analizinde Kullanılan Yöntemler}

Araştırmada kullanılan ölçeklerin geçerliğinin belirlenmesinde faktör analizi ve güvenirliklerinin belirlenmesinde ise Cronbach Alpha katsayısından yararlanılmıştır. Veriler; tanımlayıcı istatistiksel yöntemler, iki bağımsız grupta t testi, ikiden fazla bağımsız grup için tek yönlü varyans analizi, varyans analizinde gruplar arasındaki farklılı̆ın hangi grup ya da gruplardan kaynaklandığının belirlenmesi için Tukey testi, korelasyon analizi ve regresyon analizi kullanılarak analiz edilmiştir.

\subsection{Geçerlik ve Güvenirlik Analizi}

Araştırma ölçeklerinin geçerliğinin belirlenmesi amacıyla araştırma verisine faktör analizi uygulanmıştır. Örgütsel Kronizm Ölçeği için yapılan analiz sonucunda faktör analizine uygunluğun ve örneklem yeterliliğinin belirlenmesinde kullanılan KMO (Kaiser-Meyer-Olkin) değeri 0,950 olarak bulunmuştur. Literatürde KMO değerinin 0,60'ın üzerinde olması yeterli bulunduğundan (Alpar, 2013:294) elde edilen bu değer kabul edilebilirdir. Korelasyon matrisinin birim matrise eşit olup olmadığının incelenmesinde kullanılan (Alpar, 2013: 292) Bartlett Küresellik Testi sonucunda Ki-kare istatistiği 3758,814 olarak tespit edilmiş olup, bu değer istatistiksel olarak anlamlı bulunmuştur ( $\chi 2=3758,814$, sd:120, $p<0,001$ ).

Tablo 1'de verilen döndürülmüş faktör yükleri ve özdeğerler, 16 ifadenin 3 faktör altında toplandığını ve açıklanan toplam varyansın \%70,415 olduğunu göstermektedir. Faktörler, Er-

dem vd. (2013) tarafından isimlendirildiği gibi Faktör 1= işlem kronizmi; Faktör 2= terfide kronizm ve Faktör 3 = işe alma sürecinde kronizm boyutu şeklinde adlandırılmıştır. 
Tablo 1: Döndürülmüş Faktör Yükleri ve Özdeğerler

\begin{tabular}{|c|c|c|c|}
\hline Değişkenler & Faktör 1 & Faktör 2 & Faktör 3 \\
\hline $\begin{array}{l}\text { Bu hastanenin yönetim kadrosunda tanıdığı/arkadaşı olan çalışan- } \\
\text { lar, diğer kişilerden itibar görmektedir. }\end{array}$ & 0,730 & & \\
\hline $\begin{array}{l}\text { Bu hastanede, yöneticilerin tanıdıklarını/arkadaşlarını içten çıkar- } \\
\text { manın veya onlara ceza vermenin oldukça zor olduğunu düşünüyo- } \\
\text { rum. }\end{array}$ & 0,775 & & \\
\hline $\begin{array}{l}\text { Bu hastanede yetki ve sorumluluk, öncelikle yöneticilerin tanıdıkla- } \\
\text { rına/arkadaşlarına devredilmektedir. }\end{array}$ & 0,813 & & \\
\hline $\begin{array}{l}\text { Bu hastanenin yönetim kademesinde tanıdığı/arkadaşı olanlar, has- } \\
\text { tanenin kaynaklarından daha kolay yararlanmaktadır. }\end{array}$ & 0,787 & & \\
\hline $\begin{array}{l}\text { Bu hastanede yöneticilerin arkadaşı konumunda olan çalışanların, } \\
\text { diğer çalışanlara göre bir ayrıcalığı vardır. }\end{array}$ & 0,819 & & \\
\hline $\begin{array}{l}\text { Bu hastanede, yöneticilerin tanıdığı/arkadaşı olan kişilerden çekini- } \\
\text { rim. }\end{array}$ & 0,680 & & \\
\hline $\begin{array}{l}\text { Departman yöneticileri, üst yönetimde arkadaşlık ilişkileri olan çalı- } \\
\text { şanlardan çekinirler. }\end{array}$ & 0,787 & & \\
\hline $\begin{array}{l}\text { Bu hastanede çalışanların terfi ettirilmesinde, yöneticilerle olan ar- } \\
\text { kadaşlık ilişkileri öncelikle dikkate alınır. }\end{array}$ & & 0,829 & \\
\hline $\begin{array}{l}\text { Bu hastanede, hastane yöneticilerinin tanıdıklarının/arkadaşlarının } \\
\text { terfi etmesinin daha kolay olduğunu düşünüyorum. }\end{array}$ & & 0,845 & \\
\hline $\begin{array}{l}\text { Bu hastanede çalışanların terfi ettirilmesinde, bilgi, beceri ve kabili- } \\
\text { yetler ikinci planda kalmaktadır. }\end{array}$ & & 0,769 & \\
\hline $\begin{array}{l}\text { Bu hastanede çalışanların terfi ettirilmesinde, işin gerektirdiği nite- } \\
\text { likler dışındaki faktörler ön planda tutulmaktadır. }\end{array}$ & & 0,785 & \\
\hline $\begin{array}{l}\text { Bu hastanede ne kadar başarılı olursam olayım, hastane yöneticile- } \\
\text { rinin tanıdıklarının/arkadaşlarının önüne geçemem. }\end{array}$ & & 0,763 & \\
\hline $\begin{array}{l}\text { Bu hastaneye eleman alımında, hastane yönetiminin arkadaş- } \\
\text { ları/tanıdıkları önceliklidir. }\end{array}$ & & & 0,810 \\
\hline $\begin{array}{l}\text { Bu hastanede bazı görevlere, yalnızca hastane yöneticisinin arka- } \\
\text { daşları/tanıdıkları getirilmektedir. }\end{array}$ & & & 0,779 \\
\hline $\begin{array}{l}\text { Bu hastaneye eleman alımında, hastanede tanıdığı/arkadaşı olanlar } \\
\text { seçim sürecinde zorlanmazlar. }\end{array}$ & & & 0,788 \\
\hline $\begin{array}{l}\text { Bu hastanedeki bir boş pozisyona, yöneticinin herhangi bir tanı- } \\
\text { dığı/arkadaşı başvuru yaptığında, hemen işe alınır. }\end{array}$ & & & 0,776 \\
\hline Özdeğerler & 4,977 & 4,301 & 1,988 \\
\hline$\%$ & 31,109 & 26,884 & 12,422 \\
\hline Birikimli \% & 31,109 & 57,993 & 70,415 \\
\hline
\end{tabular}

İ̧̧gören performansı için ise Kaiser-Meyer-Olkin (KMO) örneklem yeterliği ölçüsünün 0,811 olarak bulunması örneklem yeterliğinin iyi olduğunu göstermektedir. Korelasyon matrisinin faktörlenebilir olup olmadığının tespit edilmesi amacıyla yapılan Barlett Küresellik Testi sonucunda Ki-kare istatistiği 738,668 olarak tespit edilmiş olup, bu değer istatistiksel olarak anlamlı bulunmuştur ( $\chi 2=738,668$, sd: $6, p<0,001)$. İşören performansı ölçeği, tek boyutlu bir ölçek olup, yapılan faktör analizi sonucunda da dört ifadenin tek boyut altında toplandığı görülmektedir. Açıklanan varyans \%75,298'dir (Tablo 2).

Tablo 2: Döndürülmüş Faktör Yükleri ve Özdeğerler

\begin{tabular}{ll}
\hline Değişkenler & Faktör 1 \\
\hline \hline Görevlerimi tam zamanında tamamlarım. & 0,902 \\
İş hedeflerime fazlasıyla ulaşırım. & 0,876 \\
Sunduğum hizmet kalitesinde standartlara fazlasıyla ulaştığımdan eminim. & 0,874 \\
Bir problem gündeme geldiğinde en hızlı şekilde çözüm üretirim. & 0,817 \\
Özdeğerler & 3,012 \\
$\%$ & 75,298 \\
Birikimli \% & 75,298 \\
\hline
\end{tabular}


Ölçeklerin geneli ve boyutları için Cronbach Alpha katsayısı Tablo 3'te verilmektedir. Tablo 3’te görüldüğü gibi çalışmada kullanılan ölçeklerin Cronbach Alpha değerleri örgütsel kronizm ölçeğinin geneli için $0,951^{\prime}$ dir ve ölçeğin boyutları için 0,850'nin üzerindedir. İşgören performansı ölçeği için bulunan değer ise 0,890 'dır. Geçerlik ve güvenirliğe ilişkin sonuçlar, ölçeklerin geçerli ve güvenilir olduklarını göstermektedir.

Tablo 3: Veri Toplama Aracının Güvenirliği

\begin{tabular}{lcc}
\hline Boyutlar & Madde Sayısı & Cronbach Alpha Katsayısı \\
\hline \hline Örgütsel Kronizm & 16 & 0,951 \\
İşlem Kronizmi & 7 & 0,876 \\
Terfide Kronizm & 5 & 0,907 \\
İşe Alma Sürecinde Kronizm & 4 & 0,901 \\
İşgören Performansı & 4 & 0,890 \\
\hline
\end{tabular}

\subsection{Araştırmanın Bulguları ve Sonuçları}

Araştırma kapsamında yer alan hastane çalışanlarının temel özelliklere göre dağııımı Tablo 4'te verilmektedir. Buna göre katılımcıların \%51,3'ünün 37 yaş ve üzerinde, $\% 71,8^{\prime}$ inin kadın, \%36,4'ünün lisans ve üzeri eğitim düzeyinde ve $\% 54,4$ 'ünün hemşire olduğu görülmektedir. Araştırmaya katılan çalışanların \%50,6'sı 12 yıl ve daha fazladır sağlık sektöründe ve \%50,3'ü ise 8 yıl ve daha fazla süredir mevcut hastanede görev yaptığı belirlenmiştir.

Tablo 4: Katılımcılara Ilişkin Tanımlayıcı Özellikler

\begin{tabular}{lcc}
\hline Değişkenler & Sayı & $\%$ \\
\hline \hline Yaş (yıl) & & \\
$\leq 36$ & 154 & 48,7 \\
$\geq 37$ & 162 & 51,3 \\
Cinsiyet & & \\
$\quad$ Kadın & 227 & 71,8 \\
$\quad$ Erkek & 89 & 28,2 \\
Eğitim Düzeyi & & \\
$\quad$ Lise & 83 & 26,3 \\
Ön lisans & 118 & 37,3 \\
$\quad$ Lisans ve üzeri & 115 & 36,4 \\
Hastanedeki Görev & & \\
$\quad$ Hemşire & 172 & 54,4 \\
Diğer Sağlık Personeli & 74 & 23,4 \\
Idari Personel & 70 & 22,2 \\
Sağlık Sektöründe Toplam Çalışma Süresi (yıl) & & \\
$\leq 11$ & 156 & 49,4 \\
$\geq 12$ & 160 & 50,6 \\
Mevcut Hastanede Çalışma Süresi (Yıl) & & \\
$\leq 7$ & 157 & 49,7 \\
$\geq 8$ & 159 & 50,3 \\
Toplam & 316 & 100,0 \\
\hline
\end{tabular}


Tablo 5'te araştırmanın değişkenlerine ilişkin istatistikler yer almaktadır. Katılımcıların örgütsel kronizm alt boyutlarına verdikleri cevapların puan ortalamalarına bakıldığında, en yüksek puanın işe alma sürecinde kronizm $(3,49)$ ve en düşük puanın ise işlem kronizmi $(3,32)$ boyutuna verildiği görülmektedir. Araştırmaya katılan çalışanların işgören performansı ortalaması 4,01'dir. Katılımcıların örgütsel kronizm ve işgören performansı algıları 5'li Likert Ölçeği ile değerlendirildiğinden, ortalama skorlar " 5 " değerine yaklaştıkça ilgili boyutun düzeyi en yükseği, "1" değerine yaklaştıkça ise en düşüğü göstermektedir. Buradan hareketle bu çalışmaya katılan çalışanların örgütsel kronizm algılarının orta düzeyde ve işgören performansı algılarının ise yüksek düzeyde olduğu söylenebilir.

Araştırma değişkenleri arasındaki ilişkilerin korelasyon katsayıları da Tablo 5 'te verilmektedir. Buna göre örgütsel kronizmin boyutları arasında $(0,765 \leq r \leq 0,800)$ pozitif yönde ve kuvvetli ilişki olduğu saptanmıştır. İ̧̧ören performansı ile örgütsel kronizmin işlem kronizmi $(r=-0,260$, $p$ ?] 0,05$)$, terfide kronizm $(r=-0,219, p<0,05)$ ve işe alma sürecinde kronizm $(r=-0,147, p<0,05)$ boyutları arasında negatif ve düşük düzeyde ilişkiler bulunmaktadır.

Tablo 5: Değişkenlerin Ortalama, Standart Sapma ve Korelasyon Değerleri

\begin{tabular}{|c|c|c|c|c|c|c|}
\hline Değişkenler & Ort & S.S. & $\begin{array}{l}\text { İşlem } \\
\text { Kronizmi }\end{array}$ & $\begin{array}{l}\text { Terfide } \\
\text { Kronizm }\end{array}$ & $\begin{array}{l}\text { İşe Alma } \\
\text { Sürecinde } \\
\text { Kronizm }\end{array}$ & $\begin{array}{l}\text { İşgören } \\
\text { Performansı }\end{array}$ \\
\hline İşlem Kronizmi & 3,32 & 0,83 & 1 & & & \\
\hline Terfide Kronizm & 3,46 & 0,92 & $0,800 * *$ & 1 & & \\
\hline $\begin{array}{l}\text { İşe Alma Sürecinde } \\
\text { Kronizm }\end{array}$ & 3,49 & 0,95 & $0,765^{* *}$ & $0,789 * *$ & 1 & \\
\hline İşgören Performansı & 4,01 & 0,80 & $-0,260 * *$ & $-0,219 * *$ & $-0,147^{* *}$ & 1 \\
\hline
\end{tabular}

Tablo 6'da araştırmaya katılan çalışanların örgütsel kronizm boyutlarına ilişkin gerçekleştiriIen analiz sonuçları verilmektedir. Katılımcıların işlem kronizmi boyutuna ilişkin puanlarının mevcut hastanede çalışma süresine $(t=-2,478 ; p<0,05)$ göre istatistiksel olarak anlamlı farklılık gösterdiği görülmektedir. Mevcut hastanede 7 yıl ve daha az süredir çalışan katılımcılar işlem kronizmi boyutuna ortalama 3,25 puan verirken, 8 yıl ve daha fazla süredir çalışan katılımcılar ise ortalama 3,38 puan vermişlerdir.

Katılımcıların terfide kronizm boyutuna ilişkin puanları eğitim düzeyleri $(F=2,807 ; p<0,05)$, hastanedeki görev $(F=2,093 ; p<0,05)$, sağlık sektöründe çalışma süresi $(t=-2,865 ; p<0,05)$ ve mevcut hastanede çalışma süresine $(t=-2,594 ; p<0,05)$ göre istatistiksel olarak anlamlı bir farklılık göstermektedir. Buna göre lise eğitim düzeyinde, idari personelde, 12 yıl ve daha fazla süredir sağlık sektöründe ve 8 yıl ve daha fazla süredir mevcut hastanede çalışanlarda terfide kronizm algısı istatistiksel olarak anlamlı şekilde daha yüksektir.

Araştırmanın katılımcılarının işe alma sürecinde kronizm algısı cinsiyetlerine $(t=2,245$; $p<0,05)$ ve mevcut hastanede çalışma sürelerine göre $(t=-2,248 ; p<0,05)$ istatistiksel olarak anlamlı şekilde farklılaşmıştır. Kadınlarda ve 8 yıl ve daha fazla süredir mevcut hastanede çalışanlarda işe alma sürecinde kronizm algısı istatistiksel olarak anlamlı şekilde daha yüksektir. 
Eskişehir Osmangazi Üniversitesi ïBß Dergisi

Tablo 6: Araştırmaya Katılan Çalışanların Çeşitli Değişkenlere Göre Örgütsel Kronizm Boyutlarına ilişskin Analiz Sonuçları

\begin{tabular}{|c|c|c|c|c|c|c|}
\hline \multirow{2}{*}{ Değişkenler } & \multicolumn{2}{|c|}{ İşlem Kronizmi } & \multicolumn{2}{|c|}{ Terfide Kronizm } & \multicolumn{2}{|c|}{ İşe Alma Sürecinde Kronizm } \\
\hline & Ort. & S.S. & Ort. & S.S. & Ort. & S.S. \\
\hline \multicolumn{7}{|l|}{ Yaş (yıl) } \\
\hline$\leq 36$ & 3,34 & 0,79 & 3,41 & 0,91 & 3,48 & 0,95 \\
\hline \multirow[t]{2}{*}{$\geq 37$} & 3,30 & 0,86 & 3,51 & 0,93 & 3,51 & 0,96 \\
\hline & \multicolumn{2}{|c|}{$t=0,415 ; p=0,678$} & \multicolumn{2}{|c|}{$t=-0,991 ; p=0,322$} & \multicolumn{2}{|c|}{$t=-0,250 ; p=0,803$} \\
\hline \multicolumn{7}{|l|}{ Cinsiyet } \\
\hline Kadın & 3,34 & 0,78 & 3,44 & 0,89 & 3,53 & 0,90 \\
\hline \multirow[t]{2}{*}{ Erkek } & 3,26 & 0,93 & 3,50 & 1,00 & 3,39 & 1,07 \\
\hline & \multicolumn{2}{|c|}{$t=0,789 ; p=0,431$} & \multicolumn{2}{|c|}{$t=-0,482 ; p=0,630$} & \multicolumn{2}{|c|}{$t=2,245 ; p=0,042$} \\
\hline \multicolumn{7}{|l|}{ Eğitim Düzeyi } \\
\hline Lise (1) & 3,35 & 0,88 & 3,60 & 0,97 & 3,54 & 1,03 \\
\hline Ön lisans (2) & 3,38 & 0,77 & 3,46 & 0,83 & 3,50 & 0,87 \\
\hline \multirow[t]{2}{*}{ Lisans ve üstü (3) } & 3,22 & 0,84 & 3,35 & 0,96 & 3,45 & 0,98 \\
\hline & \multicolumn{2}{|c|}{$F=1,138 ; p=0,322$} & \multicolumn{2}{|c|}{$\begin{array}{c}F=2,807 ; p=0,040 \\
1-3 ; p=0,042\end{array}$} & \multicolumn{2}{|c|}{$F=0,199 ; p=0,820$} \\
\hline \multicolumn{7}{|l|}{ Hastanedeki Görev } \\
\hline Hemşire (1) & 3,28 & 0,82 & 3,35 & 0,92 & 3,46 & 0,98 \\
\hline $\begin{array}{l}\text { Diğer Sağlık Perso- } \\
\text { neli (2) }\end{array}$ & 3,35 & 0,81 & 3,54 & 0,93 & 3,59 & 0,87 \\
\hline \multirow[t]{2}{*}{ İdari Personel (3) } & 3,38 & 0,87 & 3,65 & 0,89 & 3,46 & 0,97 \\
\hline & \multicolumn{2}{|c|}{$F=0,462 ; p=0,630$} & \multicolumn{2}{|c|}{$\begin{array}{c}F=2,093 ; p=0,047 \\
1-3 ; p=0,045\end{array}$} & \multicolumn{2}{|c|}{$F=0,530 ; p=0,589$} \\
\hline \multicolumn{7}{|l|}{$\begin{array}{l}\text { Sağlık Sektöründe Top- } \\
\text { lam Çalışma Süresi (yıl) }\end{array}$} \\
\hline$\leq 11$ & 3,28 & 0,80 & 3,36 & 0,92 & 3,43 & 0,98 \\
\hline \multirow[t]{2}{*}{$\geq 12$} & 3,35 & 0,85 & 3,55 & 0,91 & 3,55 & 0,92 \\
\hline & \multicolumn{2}{|c|}{$\mathrm{t}=-0,851 ; \mathrm{p}=0,395$} & \multicolumn{2}{|c|}{$t=-2,865 ; p=0,033$} & \multicolumn{2}{|c|}{$t=-1,131 ; p=0,259$} \\
\hline \multicolumn{7}{|l|}{$\begin{array}{l}\text { Mevcut Hastanede Ça- } \\
\text { Iışma Süresi (Yıl) }\end{array}$} \\
\hline$\leq 7$ & 3,25 & 0,81 & 3,32 & 0,91 & 3,42 & 0,98 \\
\hline \multirow[t]{2}{*}{$\geq 8$} & 3,38 & 0,84 & 3,59 & 0,91 & 3,56 & 0,92 \\
\hline & \multicolumn{2}{|c|}{$\mathrm{t}=-2,478 ; \mathrm{p}=0,039$} & $t=-2$ & 010 & $\mathrm{t}=-2$, &, 041 \\
\hline
\end{tabular}

Tablo 7 'de araştırmaya katılan hastane çalışanlarının işgören performansı algılarına ilişkin yürütülen analiz sonuçları verilmektedir. Katılımcıların işgören performansına ilişkin puanları yaş $(t=-2,560 ; p<0,05)$ eğitim düzeyleri $(F=4,953 ; p<0,05)$, hastanedeki görev $(F=2,752 ; p<0,05)$ ve mevcut hastanede çalışma süresine $(t=-2,434 ; p<0,05)$ göre istatistiksel olarak anlamlı bir farklılık göstermektedir. Buna göre 37 yaş ve üzerinde, lise ve lisans ve üstü eğitim düzeyinde, idari personelde ve 8 yıl ve daha fazla süredir mevcut hastanede çalışanlarda işgören performans algısı istatistiksel olarak anlamlı şekilde daha yüksektir. 
Tablo 7: Araştırmaya Katılan Çalışanların Çeşitli Değişkenlere Göre işgören Performansına ilişkin Analiz Sonuçları

\begin{tabular}{|c|c|c|}
\hline \multirow{2}{*}{ Değişkenler } & \multicolumn{2}{|c|}{ İşgören Performansı } \\
\hline & Ort. & S.S. \\
\hline \multicolumn{3}{|l|}{ Yaş (yıl) } \\
\hline$\leq 36$ & 3,99 & 0,83 \\
\hline$\geq 37$ & 4,24 & 0,77 \\
\hline & \multicolumn{2}{|c|}{$t=-2,560 ; p=0,037$} \\
\hline \multicolumn{3}{|l|}{ Cinsiyet } \\
\hline Kadın & 4,02 & 0,77 \\
\hline Erkek & 4,01 & 0,88 \\
\hline & \multicolumn{2}{|c|}{$\mathrm{t}=0,107 ; \mathrm{p}=0,915$} \\
\hline \multicolumn{3}{|l|}{ Eğitim Düzeyi } \\
\hline Lise (1) & 4,12 & 0,83 \\
\hline Ön lisans (2) & 3,83 & 0,80 \\
\hline Lisans ve üzeri (3) & 4,10 & 0,71 \\
\hline & \multicolumn{2}{|c|}{$F=4,953 ; p=0,008$} \\
\hline & \multicolumn{2}{|c|}{$1-2 ; p=0,030$} \\
\hline & \multicolumn{2}{|c|}{$2-3 ; p=0,015$} \\
\hline \multicolumn{3}{|l|}{ Hastanedeki Görev } \\
\hline Hemşire (1) & 3,98 & 0,77 \\
\hline Diğer Sağlık Personeli (2) & 4,04 & 0,79 \\
\hline \multirow[t]{3}{*}{ İdari Personel (3) } & 4,20 & 0,88 \\
\hline & \multicolumn{2}{|c|}{$F=2,752 ; p=0,045$} \\
\hline & \multicolumn{2}{|c|}{$1-3 ; p=0,038$} \\
\hline \multicolumn{3}{|c|}{ Sağlık Sektöründe Toplam Çalışma Süresi (yıl) } \\
\hline$\leq 11$ & 4,01 & 0,81 \\
\hline \multirow[t]{2}{*}{$\geq 12$} & 4,02 & 0,79 \\
\hline & \multicolumn{2}{|c|}{$t=-0,099 ; p=0,921$} \\
\hline \multicolumn{3}{|c|}{ Mevcut Hastanede Çalışma Süresi (Yıl) } \\
\hline$\leq 7$ & 3,90 & 0,79 \\
\hline \multirow[t]{2}{*}{$\geq 8$} & 4,15 & 0,80 \\
\hline & \multicolumn{2}{|c|}{$t=-2,434 ; p=0,043$} \\
\hline
\end{tabular}

Tablo 8'de örgütsel kronizm boyutlarının işgören performansı üzerindeki etkilerini ortaya koymak amacıyla yürütülen regresyon modeline ilişkin analiz sonuçları incelendiğinde, regresyon modeline ilişkin istatistiksel tahminler modelin anlamlı ve kullanılabilir olduğunu göstermektedir $(F=5,839 ; p<0,05)$. Örgütsel kronizm boyutları, katılımcıların işgören performansı algılarındaki toplam varyansın \%8'ini açıklamaktadır. Regresyon modelinde, regresyon katsayısının anlamlıığına ilişkin t-testi sonuçları incelendiğinde katılımcıların örgütsel kronizm algılarının (işlem kronizmi, terfide kronizm ve işe alma sürecinde kronizm) yükselmesi işgören performansı algılarını istatistiksel olarak azaltmaktadır. Standardize edilmiş regresyon katsayısına ( $\beta$ ) göre, değişkenlerin işgören performansı üzerindeki önem sırası terfide kronizm, işlem kronizmi ve işe alma sürecinde kronizm şeklindedir. 
Eskişehir Osmangazi Üniversitesi iißBF Dergisi

Tablo 8: Örgütsel Kronizmin Isşgören Performansı Üzerindeki Etkisine ilişkin Regresyon Analizi Sonuçları

\begin{tabular}{|c|c|c|c|c|c|c|c|c|}
\hline Bağımlı Değişken & $\begin{array}{l}\text { Bağımsız } \\
\text { Değişken }\end{array}$ & B & $\begin{array}{l}\text { Std. } \\
\text { Hata }\end{array}$ & $\beta$ & $\mathrm{t}$ & $\mathrm{p}$ & VIF & $\begin{array}{l}\text { Regresyon } \\
\text { Sonuçları }\end{array}$ \\
\hline \multirow{4}{*}{$\begin{array}{l}\text { İşgören } \\
\text { Performansı }\end{array}$} & Sabit & 3,306 & 0,238 & & 13,880 & $<0,000$ & & \multirow{4}{*}{$\begin{array}{l}R=0,294 \\
R^{2}=0,086 \\
F=5,839 \\
p=<0,000 \\
\text { DurbinWatson }=1,632\end{array}$} \\
\hline & İşlem Kronizmi & $-0,259$ & 0,081 & $-0,240$ & $-3,193$ & 0,002 & 1,917 & \\
\hline & \multirow{2}{*}{$\begin{array}{l}\text { Terfide Kronizm } \\
\text { İşe Alma Sürecinde } \\
\text { Kronizm }\end{array}$} & $-0,280$ & 0,078 & 0,273 & 3,583 & $<0,000$ & 1,959 & \\
\hline & & $-0,108$ & 0,059 & $-0,133$ & 2,139 & 0,044 & 1,959 & \\
\hline
\end{tabular}

\section{Sonuç ve Tartışma}

Bu çalışmada, sağlık çalışanlarının örgütsel kronizm ve işgören performansına ilişkin algıları ele alınarak, örgütsel kronizm algısının işgören performansı üzerindeki etkisinin belirlenmesi amaçlanmıştır. Buna ek olarak, sağlık çalışanlarının sosyo-demografik özelliklerinin örgütsel kronizm ve işgören performansı algılarında farklılık oluşturup oluşturmadığının da belirlenmesi bu araştırmada incelenmiştir.

Çalışma bulgularından hareketle, katılımcıların örgütsel kronizm alt boyutlarına verdikleri puanlar incelendiğinde, sağlık çalışanlarının örgütsel kronizm algıları orta düzeyde bulunmuştur. Sağlık çalışanları tarafından en yüksek puanın işe alma sürecinde kronizm boyutuna $(3,49)$ ve en düşük puanın ise işlem kronizmi $(3,32)$ boyutuna verildiği saptanmıştır. Denizli'de üniversite idari personeline yapılan bir çalışmada da, işe alım sürecinde kronizm algısı en yüksek, işlem kronizmi ise en düşük düzeyde bulunmuştur (Çelik ve Erdem, 2012:25). İstanbul'da belediye çalışanlarında kronizm algısının incelendiği bir çalışmada, terfi boyutunda kronizm algısı en yüksek, işlem kayırmacılığı boyutunda ise en düşük olarak tespit edilmiştir (Kurt ve Doğramacı, 2014:96). Yapılan bir başka çalışmada da terfide kayırmacılığın toplam varyansı açıklamadaki payı yüksek bulunmuştur (Asunakutlu ve Avcı, 2010:103). İş ilanları, başvuru formları, işe alım testleri, mülakatlar gibi adımların her biri insan kaynağının sağlanması sürecinde kullanılmaktadır. Ancak bu çalışma sonucunda, sağıık çalışanları, çalıştıkları kurumun insan kaynağı tedarikinde formal süreci takip etmediğini düşünmektedir.

Araştırmaya katılan sağlık çalışanlarının işgören performansı ortalaması 4,01 olarak tespit edilmiştir. Katılımcıların işgören performansı algılarının yüksek düzeyde olduğu söylenebilir. Saygılı vd. (2016:495) tarafından yapılan çalışmada da, sağlık çalışanlarının işgören performansı değişkenine iliş̧in algılamalarının yüksek düzeyde olduğu saptanmıştır. Yapılan diğer bir çalışmada da, sağlık çalışanlarının performans algısının yüksek düzeyde olduğu tespit edilmiştir (Ekiyor ve Karagül, 2016:20). Hemşirelerde de performans algısı yüksek düzeyde bulunmuştur (Eşkin Bacaksız vd., 2018:55). Sağlık kurumlarında performans, daha kaliteli hizmet sunumunda önemli bir basamak olarak düşünülebilir. Ekip halinde çalışan sağlık çalışanlarının stresli ve iş yoğunluğunun fazla olduğu bir çalışma ortamında performans algısının yüksek olması olumlu şekilde değerlendirilebilir.

Araştırma sonucunda, örgütsel kronizmin boyutları arasında pozitif yönde ve kuvvetli ilişki olduğu belirlenmiştir. İşgören performansı ile örgütsel kronizm arasındaki ilişki incelendiğinde, işgören performansı ile işlem kronizmi, terfide kronizm ve işe alma sürecinde kronizm boyutları arasında negatif ve düşük düzeyde ilişki olduğu saptanmıştır. Örgütsel kronizm işgören performansı algısındaki toplam varyansın \%8'ini açıklamaktadır. Sağlık çalışanlarının örgütsel kronizm algılarının yükselmesi işgören performansı algılarını istatistiksel olarak azaltmaktadır. Shabbir 
ve Siddique (2017:307), Pakistan'da eğitim, kalkınma ve bankacılık sektörleri gibi kamu ve özel kuruluşları inceledikleri çalışmasında, kronizmin örgütsel performansı negatif yönde etkilediği bulgusunu elde etmişlerdir. Çalışmaya göre, kronizm arttıkça örgüt performansı azalmaktadır. Cingöz ve Akilli (2015:9) ise, bu çalışmanın tersi şekilde, kronizm algısının her durumda çalışan performansını azaltmadığını belirtmektedir. Kronizm arttıkça performansın artmasının sebebi, sözleşmeli olarak çalışanlar ile kronizm yoluyla gelen çalışanlar arasında gelişen rekabetten kaynaklanıyor olabilmektedir. Cingöz ve Akilli (2015:9)'ya göre, sözleşmeli olarak çalışanlar işten kovulma korkusu yaşayabileceğinden işlerini korumak için daha iyi performans göstermeyi tercih edebilmektedir. Ancak, bu çalışma sonucunda kronizm algısının performans üzerinde olumsuz etkisi olduğu görülmüştür. Daha çok çalışsalar bile, çalışanlar terfi almada ve örgüt içi tüm süreçlerde başkalarının kendilerinden daha fazla ödüllendirilebileceğini düşünebilirler (Yan ve Bei, 2009:4). Bu sebeple, sağlık çalışanları daha yüksek performans gösterme konusunda isteksizleşebilirler ve performanslarında azalma olabilir.

Sağlık çalışanlarının işlem kronizmi boyutuna ilişkin puanları incelendiğinde, işlem kronizminin mevcut hastanede çalışma süresine göre istatistiksel olarak anlamlı farklılık gösterdiği bulgusu elde edilmiştir. Sağlık çalışanlarının mevcut hastanede çalışma deneyimi arttıkça örgüt içi işlemlerde daha kayırmacı bir tutum gösterilebilmektedir. Ancak, Kurt ve Doğramacı (2014:90), iki değişken arasında ilişkinin olmadığını belirtmektedir. Bu çalışmada işlem kronizmi boyutunda eğitim düzeyi anlamlı farklılık göstermemekle birlikte, otel çalışanlarında yürütülen başka bir çalışmada, işlem kayırmacılığı boyutunda, eğitim düzeyi yüksek mezunların işlem kronizmi konusundaki puan ortalamalarının yüksek olduğu tespit edilmiştir (Sarıboğa, 2017:77-78).

Sağlık çalışanlarının terfide kronizm algısı incelendiğinde, eğitim düzeyinin anlamlı farklılık gösterdiği ve lise eğitim düzeyinde terfide kronizm algısının daha yüksek olduğu ortaya konulmuştur. Otel çalışanlarında yürütülen başka bir çalışmada da, terfide kronizm boyutunda, eğitim düzeyi anlamlı farklılık göstermiş ve lise, ön lisans, lisans ve lisansüstü mezunlarının terfide kronizm algısı puan ortalamalarının ortaöğretim mezunlarının ortalamasından anlamlı düzeyde yüksek olduğu belirlenmiştir (Sarıboğa, 2017:77-78). Eğitimin kronizm algısını etkilemediğini ortaya koyan çalışmalar da bulunmaktadır (Kurt ve Doğramacı, 2014:93; Demaj, 2012:89; Çelik ve Erdem, 2012:28). Eğitimi yüksek olan sağlık çalışanlarının çalıştıkları kurumda yükselme beklentileri daha fazla olmaktadır. Kronizmde ise, bireylerin eğitimi, yeteneği ve becerisi dikkate alınmadan tercih söz konusu olduğu için, daha yüksek eğitimli çalışanlar bu durumun mağduru olabilirler. Kendilerinden daha düşük eğitim ve bilgi düzeyine sahip çalışanların kayırmacı bir tutumla daha yüksek pozisyonlara getirilmesi, bu çalışanların çalışma performanslarını azaltabilir ve iş tatmini, işe bağlııık vb. birçok örgütsel davranışını olumsuz şekilde etkileyebilir.

İdari personelin işgören performansı algısı, diğer sağıık çalışanlarına göre anlamlı şekilde daha yüksek bulunmuştur. İdari personel kadrosunda çalışanlarda, 12 yıl ve daha fazla süredir sağlık sektöründe ve 8 yıl ve daha fazla süredir mevcut hastanede çalışanlarda terfide kronizm algısının daha yüksek olduğu saptanmıştır. Buna ek olarak, 8 yıl ve daha fazla süredir mevcut hastanede çalışanların işe alma sürecinde kronizm algısının daha yüksek olduğu bulgusu elde edilmiştir. İdari personel üzerinde yürütülen bir başka çalışmada da, kıdemi 11-15 ve 16 yıl ve sonrası olan idari personelin, kıdemi 1-5 ve 6-10 yıl olanlara göre daha yüksek düzeyde terfide kayırmacılık yapıldığını düşündükleri tespit edilmiştir (Çelik ve Erdem, 2012:28). Bu yönüyle bu çalışma bulgularıyla benzeşmektedir. Otel işletmesi çalışanlarının ele alındığı bir başka çalışmada da, deneyim arttıkça çalışanlarda kayırmacılık algısının arttığı belirlenmiştir (Pelit vd., 
2017:58). Daha fazla süredir çalışmış olmak, terfi süreçleri ile ilgili daha fazla duruma şahit olmak anlamına gelebilir. Hem kendi deneyimleri hem de çevrede gözlenenler, bu sağlık çalışanlarını terfi konusunda kayırmacılık yapıldığını düşündürtebilir.

Sağlık çalışanlarında cinsiyete göre terfide kronizm algısında anlamlı farklılıklar bulunamamıştır. Ancak, otel çalışanları üzerinde yapılan bir çalışmada, terfide kayırmacılık boyutunda, kadınların daha yüksek ortalamalara sahip olduğu tespit edilmiştir (Sarıboğa, 2017: 74). Araştırmaya katılan sağlık çalışanlarının cinsiyete göre işe alma sürecinde kronizm algısı incelendiğinde, kadınlarda kronizm algısının daha yüksek düzeyde görüldüğü tespit edilmiştir. Yapılan çalışmalarda kadın ve erkek arasında kronizm algısı açısından anlamlı bir farklılık olmadığı bulgusunu elde eden çalışmalar da bulunmaktadır (Kurt ve Doğramacı, 2014:90; Çelik ve Erdem, 2012:28). Bu bulgunun sebebi, toplumsal cinsiyet algısı ile ilişkili olabilir. Kadın ve erkekten sosyal olarak beklenenler, çalışma hayatında beklenenleri de etkileyebilmektedir. Doğum, çocuğun büyütülmesi ve bakımı gibi süreçler, kadının iş yaşamını erkeğe göre daha fazla zorlaştırabilmektedir. Bu gibi deneyimler kadının iş yaşamını erkeğe göre daha fazla sekteye uğratabildiğinden, yöneticiler kadın çalışan alma konusunda daha temkinli davranabilirler. Ancak, sağlık hizmetlerinin her bir adımında (özellikle hemşirelik, ebelik gibi meslek gruplarında) kadın elinin önemi düşünüldügü̈nde, işe alım sürecinde kadınların kronizm algısının yüksek bulunmasının sebeplerinin daha detaylı incelenmesi yönünde çalışmalara ihtiyaç duyulmaktadır.

Araştırma bulgularına göre, 37 yaş ve üzerindeki katılımcılarda daha yüksek işgören performansı algısının olduğu belirlenmiştir. Bu durumda, sağlık çalışanlarının işgören performansına ilişkin puanlarının yaşla birlikte arttığı söylenebilir. Buna ek olarak, mevcut hastanedeki çalışma süresine göre işgören performansı algısı incelendiğinde, 8 yıl ve daha fazla süredir mevcut hastanede çalışanlarda işgören performans algısının yüksek olduğu saptanmıştır. Bu iki bulgu, yaşla birlikte artan çalışma deneyiminin sağlık hizmetleri için daha fazla tecrübe anlamına gelmesiyle açıklanabilir.

Çalışmanın bir başka bulgusu, lise ve lisans ve üzeri eğitim düzeyinde katılımcıların daha yüksek işgören performansı algısına sahip olmasıdır. Alanyazın incelendiğinde, birçok çalışmada eğitimin iş performansını olumlu anlamda etkilediği vurgulanmaktadır (Bin Shmailan, 2016:1; Tayfun ve Çatır, 2013:129; Ng ve Feldman, 2009:93). Sağlık çalışanlarında yapılan bir başka çaIışmada da, önlisans ve lisans mezunu çalışanların lise mezunu çalışanlara göre performans algısı daha yüksek bulunmuştur (Saygılı vd., 2016: 498). Sağlık kurumlarında çalışanların işe ilişkin nitelikleri büyük oranda aldıkları eğitimle ilişkili olmaktadır ve bu eğitim, büyük oranda örgütsel başarıyı etkileyebilmektedir. Daha fazla eğitim alan sağıık çalışanının işe yönelik nitelikleri daha fazla olacağından, daha yüksek performans sergileyebileceği düşünülebilir.

Çalışma sonucunda, sağıık çalışanlarının örgütsel kronizm algıları orta düzeyde bulunmuştur. Örgüt içinde kronizm algısının yerleştiği bir örgüt iklimi, çalışanlarını olumsuz anlamda etkileyerek hem çalışanların hizmet hem de örgütün başarısızlığına yol açabilir. Dolayısıyla, sağlık hizmetlerinin sunulduğu kurumlarda, kronizmin nedenleri ve sonuçlarının ortaya konmasının önemli olduğu düşünülmektedir. Kronizm algısının ortaya çıkarılmasıyla, sağılı kurumlarında konuyla ilgili düzenlemeler yapılmasına ve işe alım, terfi gibi süreçlerde resmi prosedürlerin takibine katkı sağlayabilir. 
Gelecekte yapılacak daha geniş ölçekte ve farklı sektörlerde çalışmaların kurgulanması ve sağlık kurumları yöneticilerine güvensizliğe yol açan kronizm algısını ortaya çıkaran sebeplerin belirlenmesine yönelik nitel araştırmaların yapılması önerilmektedir. Kronizm algısının performansa etkisinin incelendiği bu çalışma bulgularından hareketle, kronizmin örgüt kültürü, işe yabancılaşma gibi diğer örgütsel değişkenlerle ilişkisinin ortaya konması da alanyazına katkı sağlayabilir. 


\section{Eskişehir Osmangazi Üniversitesi IïBF Dergisi}

\section{Kaynaklar}

Abdalla, Hagen F; Maghrabi, Ahmet S; Raggad, Bel G. (1998), “Assessing the Perceptions of Human Resource Managers Toward Nepotism", International Journal of Manpower, Vol. 19 No. 8: 554 - 570.

Alpar, Reha (2013), Çok Değişkenli İstatistiksel Yöntemler, Ankara: Detay Yayıncılık.

Arasli, Huseyin; Tumer, Mustafa (2008), "Nepotism, Favoritism And Cronyism: A Study of Their Effects on Job Stress and Job Satisfaction in the Banking Industry of North Cyprus Social Behavior and Personality", Social Behavior and Personality, Vol. 36 No 9: 1237-1250.

Ashour, Ahmed Sakr (2004), "Transparency and Accountability in the Public Sector in the Arab Region". Concept Paper 3, United Nations, http://unpan1.un.org/intradoc/groups/public/documents/un/unpan015390.pdf (Erişim Tarihi: 21.09.2018).

Asunakutlu, Tuncer; Avcı, Umut (2010), "Aile İşletmelerinde Nepotizm Algısı ve İş Tatmini İlişkisi Üzerine Bir Araştırma", Süleyman Demirel Üniversitesi Iktisadi ve Idari Bilimler Fakültesi Dergisi, C.15 S.2: 93-109.

Bekiş, Tuba; Bayram, Ali; Şeker, Mustafa (2013), "Kurumsal İtibarın İşören Performansı Üzerindeki Etkisinin Belirlenmesine Yönelik Bir Araştırma", Uluslararası Alanya İ̧̧letme Fakültesi Dergisi, C.5 S.2: 19-27.

Bin Shmailan, Abdulwahab (2015), "The Relationship Between Job Satisfaction, Job Performance and Employee Engagement: An Explorative Study". Issues in Business Management and Economics, Vol. 4 No. 1: 1-8.

Büte, Mustafa (2011), “Kayırmacılığın Çalışanlar Üzerine Etkileri ile İnsan Kaynakları Uygulamaları ilişsisi: Türk Kamu Bankalarına Yönelik Bir Araştırma”, Atatürk Üniversitesi Sosyal Bilimler Enstitüsü Dergisi, C. 15 S.1: 383-404.

Büte, Mustafa; Tekarslan, Erdal (2010), “Nepotizm'in Çalışanlar Üzerine Etkileri: Aile İşletmelerine Yönelik Bir Saha Araştırması”, Ekonomik ve Sosyal Araştırmalar Dergisi, C. 6 S. 1: 1- 21.

Cemaloğlu, Necati (2007), “Örgütlerin Kaçınılmaz Sorunu: Yıldırma”, Bilig, C. 42: 111-126.

Cingöz, Ayşe; Akilli, H. Serkan (2015), The Relationship Between Organizational Trust and Job Performance: The Mediating Effect of Public Service Motivation, The 2015 WEI International Academic Conference Proceedings, Vienna, Austria.

Coco, Giuseppe; Lagravinese, Raffaele (2014), “Cronyism and Education Performance”. Economic Modelling, Vol. 38: 443-450.

Çelik, Kazım; Erdem, Ali Rıza (2012), “Üniversitede Çalışan İdari Personele Göre "Kayırmacılık”, Akdeniz Eğitim Araştırmaları Dergisi, C. 11: 23-30.

Çöl, Güner (2011), “Algılanan Güçlendirmenin İşgören Performansı Üzerine Etkileri”, Doğuş Üniversitesi Dergisi, C. 9 S.1: $35-46$.

Davis, W. Sumner (2017), “How Cronyism, Nepotism, and Unqualified Providers are Depriving You of the Best in Health Care", https://www.linkedin.com/pulse/how-cronyism-nepotism-unqualified-providers-depriving-davis-phd/ (Erişim Tarihi: 21.09.2018).

Demaj, Esmir (2012), Nepotism, Favoritism and Cronyism and Their Effects on Organizational Trust And Commitment: The Case of the Service Sector in Albania (Doctoral dissertation), Epoka University, Business Administration.

Ekiyor, Aykut; Karagül, Selçuk (2016), "Sağlık Sektöründe Personel Güçlendirmenin İşgören Performansına ve iç̧ Girişimciliğe Etkisi”, Uluslararası Sağlık Yönetimi ve Stratejileri Araştırma Dergisi, C.1 S.3: 13-25.

Erdem, Barış; Çeribaş, Sefer; Karataş, Ahmet (2013), "Otel İşletmelerinde Çalışan İşgörenlerin Kronizm (Eş Dost Kayırmacılığı) Algıları: İstanbul'da Faaliyet Gösteren Bir, İki ve Üç Yıldızlı Otel İşletmelerinde Bir Araştırma”, Çukurova Üniversitesi Iktisadi ve Idari Bilimler Fakültesi Dergisi, C. 17 S.1: 51-69.

Erdem, Barış; Karataş, Ahmet (2015), "The Effects of Cronyism on Job Satisfaction and Intention to Quit the Job in Hotel Enterprises: The Case of Three, Four and Five Star Hotels in Muğla, Turkey", Manas Journal of Social Studies, Vol. 4 No. 1: 55-74.

Ergun Ozler, N. Derya; Buyukarslan, B. Alper (2011), "The Overall Outlook of Favoritism in Organizations: A Literature Review", International Journal of Business and Management Studies, Vol. 3 No. 1: 275-285.

Eşkin Bacaksız, Feride; Tuna, Rujnan; Harmancı Seren, Arzu Kader (2018), "Sağlık Çalışanlarında Performans ve Örgütsel Sinizm İlişkisi: Hemşireler Üzerinde Bir Araştırma”, Acıbadem Üniversitesi Sağlık Bilimleri Dergisi, C.9 S.1: 52-58.

Feinberg, Carmen (2018), "Cronyism: The One Not-So-Obvious Mistake That Can Destroy Company Culture", https://www.forbes.com/sites/forbeshumanresourcescouncil/2018/06/04/cronyism-the-one-not-so-obviousmistake-that-can-destroy-company-culture/\#3b8ec1966d92 (Erişim Tarihi: 21.09.2018). 
Ford, Robert; McLaughlin, Frank (1985), “Nepotism”, Personnel Journal, Vol 64: 57 - 61.

Fu, I-Pang (2015), "Favoritism: Ethical Dilemmas Viewed through Multiple Paradigms", The Journal of Values-Based Leadership, Vol. 8 No. 1: 1-7.

Güner, Gürkan (2015), Özel Hastanelerde Performans Yönetiminin Değerlendirilmesi: Ankara'ya Yönelik Bir Çalışma, Yüksek Lisans Tezi, Ufuk Üniversitesi Sosyal Bilimler Enstitüsü, Ankara.

Gürer, Alper; Deniz, Nevin (2017), “Algılanan Örgütsel Kronizmin Çalışan Sessizliği Üzerindeki Etkisinde Kişiliğin Düzenleyici Rolü”, The Journal of Academic Social Science Studies, C. 59: 475-500.

İraz, Rıfat; Akgün, Özlem (2011), Örgütsel Bağlılığın Çalışan Performansı Üzerine Etkilerini Ölçmeye Yönelik Bir Araştırma, Selçuk Üniversitesi Sosyal Bilimler Meslek Yüksekokulu Dergisi, C. 14 S. 1-2: 201-224.

Keleş, Hatice Necla; Kıral Özkan, Tuğba; Bezirci, Muhammet (2011), "A Study on the Effects of Nepotism, Favoritism and Cronyism on Organizational Trust in the Auditing Process in Family Businesses in Turkey" The International Business \& Economics Research Journal, Vol. 10 No. 9: 9-16.

Kesen, Mustafa; Kaya, Nihat (2016), “Çalışan Performansının Örgütsel İmaj ve Psikolojik Sermaye Bağlamında İncelenmesi: Vakıf Üniversiteleri Örneği", The Journal of Academic Social Science Studies, C. 46: 187-198.

Khatri, Naresh; Tsang, Eric WK (2003), “Antecedents and Consequences of Cronyism in Organizations”, Journal of Business Ethics, Vol. 43: 289-303.

Khatri, Naresh; Tsang, Eric WK; Begley, Thomas M. (2006), "Cronyism: A Cross-Cultural Analysis", Journal of International Business Studies, Vol. 37: 61-75.

Kirkman, Bradley L; Rosen, Benson (1999), "Beyond Self-Management: Antecedents and Consequences of Team Empowerment", Academy of Management Journal, Vol. 42 No. 1: 58-74.

Kurt, Ebru; Doğramacı, Bahar (2014), “Terfi, İşlem Kayırmacılığı ve İşe Alma Boyutlarında Kayırmacılık Davranışı Algısının Ölçülmesi: İstanbul İlinde Faaliyet Gösteren Bir Belediye İştirakinde Çalışanlar Üzerine Bir Araştırma”, Elektronik Mesleki Gelişim ve Araştırmalar Dergisi, C. 2: 82-96.

Leung, T. K. P; Barnes, Bradley R. (2016), “Examining Structural Cronyism and Organizational Performance”, Working Paper, Research Institute for Business.

Loewe, Markus; Blume, Jonas; Schönleber, Verena; Seibert, Stella; Speer, Johanna; Voss, Christian (2007), "The impact of favouritism on the business climate: A study on wasta in Jordan, Studies", Deutsches Institut für Entwicklungspolitik, 30, German Development Institute (DIE), Germany.

Ng, T. W; Feldman, Daniel C. (2009), “How Broadly Does Education Contribute to Job Performance?”, Personnel Psychology, Vol. 62: 89-134.

Özer, Niyazi; Çağlayan, Zeynep Asya (2016), “Öğretmenlerin Müdürlerine Duydukları Güven ve Kronizm Algıları Arasındaki İlişki”, İnönü Üniversitesi Eğitim Bilimleri Enstitüsü Dergisi, C.3 S. 5: 16-27.

Pearce, Jone L. (2015), “Cronyism And Nepotism Are Bad for Everyone: The Research Evidence”, Industrial and Organizational Psychology, Vol. 8 No. 1, 41-44.

Pelit, Elbeyi; Baytok, Ahmet; Soybalı, H. Hüseyin; Kılıç, Ibrahim (2017), "The Role of Demographic Characteristics in the Nepotism Perception: An Application on the Hotel Business Employees", Journal of Turkish Tourism Research, Vol. 1S. 2: $45-63$.

Sarıboğa, Merve (2017), Nepotizmin Örgütsel Bağlılık ve İş Doyumuna Etkisi ve Otel Çalışanları Üzerine Bir Araştırma, Yüksek Lisans Tezi, Doğuş Üniversitesi Sosyal Bilimler Enstitüsü, İstanbul.

Saygılı, Meltem; Erigüç, Gülsün; Özer, Özlem (2016), "Sağlık Çalışanlarının Örgütsel Sessizlik ve Çalışan Performansı Düzeylerinin Belirlenmesi", The Journal of Academic Social Science Studies, C. 49: 485-500.

Shabbir, Benish; Siddique, Hassan (2017), "Impact of Nepotism, Cronyism, and Favoritism on Organizational Performance with a Strong Moderator of Religiosity", International Journal of Scientific and Engineering Research, Vol. 8 No. 4: 299-309.

Shaheen, Sadia; Bashir, Sajid; Khan, Abdul Karim (2017), “Examining Organizational Cronyism as an Antecedent of Workplace Deviance in Public Sector Organizations", Public Personnel Management, Vol. 46 No. 3: 308-323.

Sigler, Tracey Honeycutt., \& Pearson, Christine M. (2000), “Creating an Empowering Culture: Examining the Relationship Between Organizational Culture and Perceptions of Empowerment," Journal of Quality Management, Vol. 5: 27-52.

Tayfun, Ahmet; Çatır, Ozan (2013), “Örgütsel Sessizlik ve Çalışanların Performansları Arasındaki İlişki Üzerine Bir Araştırma”, İşletme Araştırmaları Dergisi, C. 5 S. 3: 114-134. 


\section{Eskişehir Osmangazi Üniversitesi IïBF Dergisi}

Tunçbilek, Mehmet Murat; Akkuş, Adil (2017), “Nepotizm (Akraba Kayırmacılığı) ve İş Tatmini Arasındaki iliş̧ki ve Safranbolu Konaklama İşletmelerinde Bir Araştırma”, Yüzüncü Yıl Üniversitesi Iktisadi ve Idari Bilimler Fakültesi Dergisi, C. 3: 169-197.

Turhan, Muhammed (2014), "Organizational Cronyism: A Scale Development and Validation from the Perspective of Teachers". Journal of Business Ethics, Vol. 123 No. 2: 295-308.

Tutar, Hasan; Altınöz, Mehmet (2010), "Örgütsel İklimin İşgören Performansı Üzerine Etkisi: Ostim İmalat İşletmeleri Çalışanları Üzerine Bir Araştırma”, Ankara Üniversitesi Siyasal Bilgiler Fakültesi Dergisi, C. 65 S. 2: 196-218.

Yan, Yang; Bei, Hu (2009), "Notice of Retraction the Antecedents of Organizational Cronyism", In Management and Service Science, International Conference, September, 1-5.

Yelboğa, Atilla (2006), "Kişilik Özellikleri ve İş Performansı Arasındaki İlişkinin İncelenmesi”, İş, Güç Endüstri iliş̧kileri ve insan Kaynakları Dergisi, C. 8 S. 2: 196-211. 